\title{
REFLEXÕES SOBRE O PAPEL DA MULHER EM RELAÇÃO AO DESEJO SEXUAL
}

\author{
Jaqueline Brendler ${ }^{l}$
}

\section{REFLECTIONS ON WOMEN'S ROLE REGARDING SEXUAL DESIRE}

Resumo: O desejo sexual é dissecado, nos seus conceitos atuais, nas suas variáveis, nos seus estimulantes e nos seus supressores. Os comportamentos clássicos e os contemporâneos usados na aproximação afetivo-sexual que demonstram e/ou provocam desejo sexual são relatados, da linguagem corporal às táticas usadas nos sites de namoro na internet. $\mathrm{O}$ texto ainda inclui o papel da mulher, num contexto de sexualidade satisfatória e disfuncional, em: 1 - permitir-se ter desejo sexual; 2 - desencadear/ provocar o seu próprio desejo sexual, com a ajuda ou não do(a) parceiro(a) sexual; 3 - despertar o apetite sexual do parceiro.

Palavras-chave: Papel da mulher; sedução; desejo sexual.

\begin{abstract}
Sexual desire is dissected, in its current concepts, its variables, its stimulants, and its suppressants. Classic behaviors as well as contemporary behaviors used for affective-sexual approach showing and/or provoking sexual desire are reported, from body language to the tactics used in dating websites. The text also includes women's role - within a context of a fulfilling and dysfunctional sexuality - for: 1 - allowing herself to feel sexual desire; 2 - triggering/provoking her own sexual desire, with or without her sexual partner's help; 3 - awakening her partner's sexual appetite.
\end{abstract}

Keywords: Woman's role; seduction; sexual desire.

1 Ginecologista. Título de Especialista em Sexualidade Humana / SBRASH e Certificação em Sexologia / AMB e FEBRASG0. Conselho Deliberativo SBRASH 2005-07.Comitê de Ética da FLASSES 2004-08.Comitê Científico da Associação Mundial de Saúde Sexual (WAS) 2007-09. e-mail: jaqbrendler@terapiadosexo.med.br 


\section{O conceito sobre desejo sexual}

Em relação ao conceito sobre desejo sexual são poucos os da literatura, pois a maioria das publicações científicas estuda mais a disfunção do desejo do que o desejo sexual.

Para Kaplan,

[..] é uma força que impele homens e mulheres a procurar, iniciar e/ou responder à sexual estimulação; que não é meramente uma subjetiva sensação, nem é meramente um estado mental. Desejo sexual é um motivacional e/ou um estado impulsivo/instintivo que é gerado por um específico processo neurofisiológico no cérebro (KAPLAN, 1995, p.15)

Segundo outros pesquisadores (ROSEN, RILEY, WAGNER, OSTERLOH, KIRKPATRICK \&, MISHRA, 1997), "É um sentimento que pode incluir vontade de ter uma experiência sexual, for meio de intercurso ou masturbação, pensar sobre ter sexo ou o sentimento de frustração pela falta de sexo". Para Levine (2003), é "uma soma de forças que nos inclina e nos impele para o comportamento sexual", contudo ele cita que muitos colegas acadêmicos pensam que o desejo sexual pode ser uma "excitação inicial" e sugere o termo "desejo excitatório".

\section{O desejo sexual}

Segundo Kaplan (1995), há seis pontos na escala do desejo sexual humano, com o desejo sexual hiperativo ocupando o topo e a aversão sexual, o ponto mais baixo, sendo eles: 1 - Desejo sexual hiperativo; 2 - Desejo sexual normal alto; 3 - Desejo sexual normal baixo; 4 - Desejo sexual hipoativo leve; 5 Desejo sexual hipoativo grave; 6-Desordem da aversão sexual. No que ela considera desejo sexual normal alto há espontâneo desejo sexual e fantasias, comportamento sexual pró-ativo, normal funcionamento sexual, alta freqüência sexual, sendo mais comuns em homens. No desejo sexual normal baixo não há espontâneo desejo sexual e fantasias, há um comportamento sexual receptivo, normal funcionamento sexual, e média ou baixa freqüência sexual.

Kaplan (1995) pensa que há excitantes e supressores psicológicos para o desejo sexual que atuam nos centros sexuais cerebrais, principalmente no hipotálamo e no sistema límbico. Entre os excitantes emocionais estão: 1 - Parceiro(a) atraente; 2 - Parceiro(a) congruente com a fantasia sexual; 3 - Parceiro(a) sedutor(a); 4 - Parceiro(a) responsivo(a); 5 - Ambiente favorável; 6-Fantasias sexuais; 7-Amor; 8-Novidade; 9-Adequada estimu- 
lação física; 10 - Ausência de emoções e pensamentos negativos; 11 - Situação favorável. Entre os supressores psicológicos do desejo sexual, além das situaçôes opostas, as citadas como excitantes, ela relata a existência de antifantasias sexuais (imagens mentais negativas, aversivas, repulsivas, de medo, simulando desvantagens ou perigo que evocam uma situação de emergência emocional que diminui o apetite sexual), amor por outra pessoa, a depressão, a raiva, a ansiedade e a excessiva familiaridade. No caso da Desordem do Desejo Sexual Hipoativo (HSDD), essa autora reforça que é essencial, além de resolver o conflito, restabelecer os excitantes sexuais e remover os supressores para que o desejo seja restabelecido. Ela ainda destaca que algumas características femininas, como a juventude, o potencial procriativo, cabelos com brilho, andar cambaleante, voz doce e sedutora, roupas sensuais que revelam a forma dos seios e das pernas, tanto quanto um comportamento acariciante, submisso, bem educado e a expectativa de completude sexual atraem os homens e diz que esse ainda é um comportamento de corte.

Ela menciona que os humanos evoluíram além do "estrus" e ressalta que os hormônios sexuais são importantes somente na sua ausência, pois haverá interferência na diferenciação dos genitais, na masculinização ou na feminização do cérebro fetal, no desenvolvimento das características sexuais secundárias e na forma final corporal. Em relação aos hormônios ela reconhece também que existe a deficiência androgênica em mulheres e a no homem idoso.

Levine (2003) diz que o ordinário espectro da intensidade do desejo sexual segue a seguinte dinâmica, sendo os dois extremos, as situaçôes de maior intensidade negativa e positiva respectivamente: aversão - desinclinação indiferença - interesse - necessidade - paixão/desejo carnal. Fischer (1995 e Brendler (2002) confirmam que a paixão eleva o apetite sexual. Brendler (2002) ressalta que manter o desejo sexual além do período da paixão será mais fácil, se existir internalizado na mulher a identificação primária com mulher sexuada. Cita que a paixão pode mascarar a inexistência da falta dessa identificação, o que vai tornar-se perceptível num relacionamento de longo prazo, quando irá surgir o HSDD.

O desejo sexual, para Levine (2003), é sempre composto de três componentes: 1 - Impulso, instinto sexual (componente biológico); 2 - Motivação (componente psicológico individual e / ou do relacionamento); 3-Querer / requisitar (componente cultural). Esse autor relata que quatro são as variáveis que mais influenciam o impulso / instinto e a motivação sexual, modelando a tendência do ser humano comportar-se ou não de modo sexual: a situação social, a idade, o gênero e a saúde. 
Em relação às diferenças do gênero, em relação ao desejo sexual, Levine (2003) menciona que são um interessante desafio. Diz que a mulher aspira ter intimidade emocional como um portão para o sexo, ao passo que o homem é mais facilmente inclinado a aspirar o comportamento sexual como uma via para a proximidade; desse modo, o impulso /instinto sexual e a necessidade de intimidade serão com freqüência negociados no contexto do casal e na clínica sexológica. Ele menciona que as negociaçôes em casais heterossexuais devem lidar com o modelo linear, aplicado aos homens (desejo-excitação-orgasmo-resolução) e o modelo circular, aplicado 'as mulheres que interliga impulso/instinto, motivação, intimidade, excitação e orgasmo'. Já nos casais homossexuais, as necessidades de intimidade emocionais e sexuais são diferenças individuais e não de gênero.

Onze são os estimulantes do desejo sexual para esse estudioso, entre os quais há estímulos ilusórios e outros reais: 1 - Intimidade psicológica; 2 Apaixonamento; 3 - Ver, ler sobre, ou escutar pessoas tendo explicitamente sexo prazeroso; 4 - Ver, ler sobre, ou escutar uma romântica seqüência, entre duas atraentes pessoas; 5 - Invocar uma fantasia que tenha sido confiavelmente erótica no passado; 6 - Esperar engravidar; 7 - Usar uma variedade pequena de drogas em baixas doses e ocasionalmente medicação; 8 - Instrução; $8 \mathrm{a}$ - Aprender e transcender culturais proibições internalizadas contra a expressão sexual e $8 \mathrm{~b}$ - Aprender novas maneiras de olhar a vida, como na ioga, no budismo e na ciência; 9 - Reparar um recente problema de relacionamento; 10 - Conquistar um amor errante; 11 - Ter uma disfunção sexual sem esperança de solução, tratada com sucesso.

Na tradução de Brendler (2005c), do Modelo Circular de Rosemary Basson, é descrito que um responsivo tipo de desejo sexual e a excitação sexual ocorrem simultaneamente, depois que a mulher deliberadamente escolhe experienciar estimulação sexual. Esta escolha é baseada em necessidades, do tipo ganhos e recompensas (intimidade emocional, compromisso, tolerância às imperfeições do relacionamento, bem-estar do parceiro, dividir prazer físico com o parceiro) mais do que desejo para experienciar excitação física e liberação orgásmica. Qualquer um desses futuros ganhos podem ser uma força motivacional isolada, como também pode ser acompanhada de física necessidade ou apetite sexual espontâneo, integrando, assim, desejo sexual responsivo e "espontâneo" (desencadeado por pensamentos, fantasias, apetite sexual consciente), embora esse último, isoladamente, é típico de homens e mais raro em relacionamentos de longo prazo, em mulheres. Menciona que prazerosa experiência física é necessária para que esta sugerida motivação não sexual continue em longo prazo. Então, a mulher, numa situação de 
neutralidade sexual, visando obter um conjunto de recompensas que aumentam a intimidade emocional com o parceiro, procura estímulos/sinais sexuais, entra numa experiência erótica/sexual, sente excitação psicológica e desejo sexual o que provoca excitação física sexual. O desejo sexual, assim desencadeado, coincide ou é posterior à excitação sexual, e juntos levam à emocional e física satisfação.

Saliento que há diferenças entre a excessiva familiaridade e a intimidade, pois a primeira é um supressor sexual e a segunda é um estimulante, principalmente para as mulheres. A intimidade que atende na sua definição legítima à um conceito dinâmico que nunca é completado o que inclui afeição mútua, suporte para com o outro, crescimento pessoal, revelação de si mesmo e do outro, além do compartilhar nas áreas emocional, sexual, social, intelectual e recreacional. $\mathrm{O}$ modelo de intimidade sexual que mais permite novas pontes para o desejo sexual segundo Lobitz \& Lobitz (1986) é aquele no qual há uma integração da diferenciação (de cada um) com compaixão, com empatia e com honra para com as diferenças do outro. Há aprovação e conexão com a identidade, com comportamento e com as diferenças do outro. Há confiança em si mesmo, no outro e no relacionamento. Assim, há permissão para explorar comportamentos e fantasias sexuais em novos, excitantes, misteriosos e poderosos caminhos.

O que desperta o desejo sexual é igual para os dois sexos? A publicação de Pease e Pease (2000) menciona que os homens são estimulados pela pornografia, pela nudez feminina, pela variedade sexual, pelas roupas íntimas e pela disponibilidade da mulher. Elas têm seu apetite sexual acionado pelo romance, pelo compromisso, pela comunicação, pela intimidade, pelo toque não-sexual.

\section{O ritual de aproximação afetiva e/ou sexual}

Para descrever o processo de aproximação afetivo e/ ou sexual prefiro iniciar mencionando o zoólogo inglês (MORRIS, 2005, p. 12-13) que diz que tanto homens quanto mulheres são cem vezes mais neotônicos (processo evolucionário que permite aos humanos manter caracteres juvenis na vida adulta) que machos e fêmeas de outras espécies. As diferenças entre homens e mulheres são verdadeiras e muito interessantes, mas muito leves. À medida que o homem e a mulher percorriam seu trajeto evolutivo em direção a uma neotonia cada vez maior, o homem se comportava de maneira cada vez mais infantil e mostrava menos mudanças físicas, enquanto que a mulher desenvolvia mais atributos físicos e menos qualidades mentais infantis. 
Em relação ao homem ser mais ligeiramente infantil em seu comportamento do que a mulher, esse autor diz que esse comportamento se deve a uma diferença entre o cérebro da mulher e o do homem; assim, os homens tornaram-se mais imaginativos e, às vezes, perversos; as mulheres tornaram-se mais sensíveis e carinhosas. Essas diferenças se adaptam ao seu papel na sociedade. Eles se complementam, e a combinação resultou em sucesso.

Ele fala que em relação à evolução física, historicamente, por causa da divisão de trabalho, os homens precisavam ser mais fortes e mais atléticos para a caça. O corpo do homem é 30\% mais forte, $10 \%$ mais pesado e $7 \%$ mais alto do que o corpo da mulher. Devido à sua importância para a reprodução, o corpo feminino tinha que ser protegido da fome. Por isso, o corpo arredondado da mulher contém em média $25 \%$ de gordura, enquanto o masculino tem apenas $12,5 \%$. Essa grande retenção de gordura na fêmea era uma característica fortemente infantil, e com ela vieram muitos outros atributos juvenis. O homem adulto foi programado pela evolução para proteger seus filhos. A reação paterna ao corpo gordinho de seus bebês era tão forte que podia ser explorada pela fêmea adulta. Quanto mais características de bebê apresentasse, mais proteção ela conseguiria de seu macho. A exemplo disso, a voz da mulher permaneceu num tom mais agudo do que a do homem, ou seja, a mulher manteve uma voz semelhante à das crianças.

Ele se pergunta: Qual é a atração dos cabelos loiros, um apelo tão forte a ponto de criar a bizarra situação de termos no mundo mais loiras artificiais do que verdadeiras? A resposta encontrada nos seus estudos é que a mulher loira passa uma imagem mais juvenil do que a morena. Essa imagem, projetada numa mulher adulta, aumenta o seu poder de sedução, transmitindo fortes sinais de que ela deseja ser cuidada. Ele cita que as loiras passam uma idéia de juventude porque, em grande parte da humanidade, os bebês são mais louros que seus pais (MORRIS, 2005, p.27).

Outro exemplo da preservação de uma característica infantil são os lábios. Como a fêmea humana é um pouco mais evoluída anatomicamente, ou seja, mais juvenil que o homem nesse aspecto, seus lábios são, em média, mais protuberantes. O que torna os lábios tão sensuais visualmente? Em sua forma, em sua textura e em sua coloração, eles imitam os outros lábios femininos, os lábios vaginais. Enquanto a mulher for jovem e o sexo lhe ocupar a mente, ela tratará de cuidar dos lábios como um símbolo sexual. Ela os umedece, os cobre de batom, faz biquinho, sopra beijos (MORRIS, 2005, p.83-84).

Sobre as nádegas, esse estudioso esclarece que os músculos glúteos se destinam a manter a postura ereta e nas mulheres, em relação ao tamanho corporal, 
são maiores do que as dos homens, porque têm maior quantidade de tecido adiposo. Outro atributo feminino é que a mulher tem as costas mais arqueadas do que a do homem. Em posição normal de repouso, o traseiro se projeta mais para fora que o do homem, não importa o seu tamanho. Quando ela caminha, a estrutura óssea das pernas e dos quadris provoca uma ondulação maior da região glútea. Quando esses três atributos - mais gordura, maior protusão e mais ondulação - se combinam, o resultado é um forte apelo erótico (MORRIS, 2005, p.210).

Por que o par de seios atrai os homens? As fêmeas das outras espécies emitem sinais sexuais com o traseiro, enquanto caminham sobre as quatro patas. $\mathrm{O}$ traseiro da fêmea humana também é capaz de enviar fortes sinais eróticos, quando a mulher é vista de costas, mas ela não anda de quatro. Ela caminha ereta e é vista de frente, na maioria das situaçōes sociais. Quando ela se coloca em frente a um homem, o par de falsas nádegas que ela traz no peito lhe permite continuar transmitindo o primitivo sinal, sem dar as costas ao interlocutor (MORRIS, 2005, p. 141).

Eibl-Eibesfeldt (1989), após estudar filmagens realizadas em diferentes continentes, estabeleceu o padrão feminino para o flerte. Ele cita que a mulher primeiro sorri para o seu admirador e ergue as sobrancelhas num movimento rápido, enquanto abre bem os olhos para olhar para ele; a seguir, baixa as pálpebras, inclina levemente a cabeça para o lado e desvia os olhos. Após isso, é comum cobrir o rosto com as mãos, de modo a escondê-lo enquanto dá umas risadas nervosas. Ele diz que essa atitude seqüencial da paquera é um traço que se vem desenvolvendo por milhóes de anos e demonstra o interesse sexual. Outra atitude antiga para iniciar namoro é o olhar recatado, no qual a mulher abaixa a cabeça e olha timidamente para cima, na direção do homem a ser conquistado. Outras atitudes das mulheres para solicitar atenção são erguer os ombros, arquear as costas e jogar o cabelo para trás, tudo num só movimento coordenado.

No ocidente esse autor menciona que é muito freqüente homens e mulheres olharem intencionalmente para um pretendente, por dois a três segundos e, nesse tempo, se suas pupilas se dilatarem é um sinal de interesse intenso. Ele e outros colegas etólogos denominaram esse olhar de "olhar de desejo". Fischer (1995) diz que ninguém fica indiferente a um olhar fixo, pois ele exige uma reação, mas primeiro é realizado um movimento para disfarçar, para aliviar a ansiedade, enquanto se pensa na resposta em aceitar ou não o jogo da sedução. Essa autora fala do "sorriso superior" que demonstra um interesse maior da pessoa, e nele se mostra os dentes superiores a fim de 
deixar claro as intenções de aproximação, e ele vem quase sempre acompanhado de um rápido erguer de sobrancelhas. Eibl-Eibesfeldt (1989) os observou em vários continentes, e diz que é utilizado para todos os tipos de amizade, incluindo o flerte. Fischer (1995) diz que já "o sorriso aberto" com os lábios totalmente abertos e mostrando os dentes superiores e inferiores é o que é utilizado no namoro.

Segundo o entendimento de Givens (1983) e de Perper (1985) essas atitudes de namoro acima citadas fazem parte de um conjunto maior "a dança do acasalamento humano". Esses estudiosos, observando pessoas em bares de solteiros nos EUA e no Canadá, verificaram o namoro, o processo de escolha em cinco estágios. O primeiro deles é "chamar a atenção" após a escolha do território em que vão ficar, e para isso usam táticas diversas, as mulheres jovens para chamar atenção sorriem, olham, mudam de posição, rebolam, ajeitam-se. Além disso, usam movimentos femininos como: enrolar o cabelo com os dedos e o jogar para trás, olham com olhar tímido, estalam a língua, umedecem o lábio superior, coram e escondem o rosto, além dos comportamentos citados por Eibl-Eibesfeldt (1989), enviando a mensagem "estou aqui”. No flerte Fischer (1995) diz que as mulheres podem usar um andar exibicionista que, além do descrito por Eibl-Eibesfeldt (1989) (estufar o peito e arquear as costas), inclui o andar cambaleante, já mencionado por Morris (2005). Ela ainda cita que esse andar é facilitado com o uso do salto alto que por si só levanta as nádegas, pois causa um retraimento artificial das costas na altura da cintura e estufa o peito, além disso, menciona que o barulho dos saltos também ajuda a chamar a atenção. Essa antropóloga relata que as mulheres mostram a sua disponibilidade aos homens pelo conjunto de uma ou mais dessas atitudes como: usar o salto alto, ao fazer "biquinho" com os lábios, virar a ponta dos pés para dentro e rebolar, entre outros já anteriormente mencionados.

A segunda fase do processo de escolha é a do "reconhecimento" e começa quando os olhares se encontram.

A terceira fase é a "conversa” que ocorre após o cruzamento de olhares seguido do aceite, que pode ser através de um sorriso ou de mudança corporal. Essa é considerada por muitos estudiosos a etapa mais difícil e Morris (1983) a denominou "conversa da sedução". Na conversa que pode iniciar com frases nada importantes, para quebrar o gelo, sendo que os especialistas aconselham perguntas ou elogios, pois ambos exigem uma resposta. Na conversa da sedução, o conteúdo é menos importante do que a forma como é dito. Usar um tom mais al to de voz e falar de maneira amável ou carinhosa é muitas vezes um 
sinal de interesse sexual. Se durante a conversa o parceiro rir mais do que o convencional, para a situação, ele também provavelmente estará flertando, diz Fischer (1995). A conversa também vai relevar um pouco sobre a educação, a graduação e a vida dos parceiros, por isso também é considerada um ponto crítico, para que se passe para o quarto estágio, o contato físico.

O contato físico começa com "atitudes de intenção": inclinação do corpo, colocar um braço próximo ao outro, aproximação dos pés (se estão de pé), ou um deles acaricia o próprio braço, como se estivesse acariciando o outro. Depois vem o toque no corpo do outro, em regiōes, como o ombro, o punho, o antebraço, lugares socialmente permitidos, o que geralmente é feito, inicialmente pela mulher, de forma casual, mas calculada. Se o toque for ignorado, nova tentativa de toque sutil poderá ser feita, mas se o receptor sorrir, inclinar o seu corpo em direção à pessoa ou retribuir o toque, é sinal de que o flerte está progredindo. Se esse processo de aceitação e retribuição do toque continuar em meio a sorrisos e à conversa, inclinando em direção ao outro, em geral, o casal vai para o quinto e último estágio do processo de escolha: a total sincronia corporal.

Os movimentos podem no início ficarem sincronizados, ou seja, ela eleva a taça de vinho e ele também e depois podem perder a sintonia, mas à medida que os dois vão sentindo-se à vontade, os movimentos vão tornando-se similares. A exemplo disso é que quando ele cruza as pernas, ela cruza as dela, quando ele se inclina para a direita, ela também o faz, enquanto olhamse nos olhos. Fischer (1995) diz que, quando nos sentimos atraídos por um parceiro, começamos a nos movimentar no mesmo ritmo.

É importante citar que Morris (1983) descreve doze etapas no galanteio humano que são nessa ordem: 1 - Olhar o corpo; 2 - Olhar nos olhos; 3 - Intercâmbio vocal; 4 - Mão na mão; 5 - Braço no ombro; 6 - Braço na cintura; 7-Boca na boca; 8 - Mão na cabeça; 9 - Mão no corpo; 10 - Mão no sexo; 11 - Boca no peito; 12 - Sexo no sexo.

\section{A internet, a "era fast" e o processo de sedução}

Segundo Brendler (2007), o século XX se caracterizou pela "Era do tudo é eterno", pela "Era do divórcio" e pela "Era Fast" que continua nos dias atuais. No final dos anos 90, com popularização da internet e do telefone celular, somado às descobertas farmacológicas para melhorar a sexualidade disfuncional masculina, o mundo entrou na "Era Fast", era da aceleração e de 
grande transitoriedade em todos os tipos de vínculos, sejam os sociais, os profissionais, os afetivo-sexuais ou unicamente sexuais.

A Era Fast, segundo a autora, é fruto das fantásticas tecnologias (online, digitais, farmacológicas) criadas inclusive com o objetivo de facilitar e dar mais qualidade à vida das pessoas e conseqüentemente lhes permitir mais tempo livre para usufruir mais alegrias e prazeres.

Das tecnologias da Era Fast, a mais importante no jogo da sedução éa internet, pois desde a sua criação a aproximação afetiva-sexual tem apresentado algumas mudanças, uma vez que a rede apresenta cada vez mais produtos.

No Brasil a exploração comercial da internet iniciou, em 1995, e a pesquisa Ibope/NetRatings publicada, na Zero Hora, informa que o Brasil é líder em tempo de navegação na internet, no mês de maio de 2007, uma vez que 17,9 milhões de internautas residências acessaram a rede pelo menos uma vez ao mês, e o tempo médio de navegação por usuário residencial foi 23 horas e 43 minutos, sendo que pessoas que a acessam em qualquer ambiente foi de 33,1 milhões no país.

Hoje, para ser visto, o que facilita a atração sexual, nas vitrines virtuais da rede pode-se usar sites de relacionamento como Orkut.com, MySpace.com, o YouTube.com, o Facebook.com ou os fotoblogs. O fotolog.com, em 26/ 08/07, tinha mais de 10 milhōes e 668 mil usuários no mundo, já no Brasil, o estado de São Paulo estava em primeiro lugar e em $7^{\circ}$ o Rio Grande do Sul. Em todos os países há eleição dos fotologs mais populares. Os fotologs são mais freqüentados por adolescentes que nasceram mergulhados no ciberespaço, no qual há o império da imagem sobre a palavra.

O portal Orkut.com, no qual as pessoas participam de comunidades e grupos de amigos, dia 26/8/2007 continha 69.378 .730 membros, os brasileiros são a segunda maior comunidade, com 1.165 .108 membros, só perdendo para os americanos, sendo os paulistas os líderes brasileiros no Orkut.

No Brasil, o setor de sites específicos de namoro é liderado pelo Parperfeito. com.br, que exibe perfis com foto e sem fotos, de milhares de brasileiros que buscam de sexo a casamento; esse site acessado dia 26/8/2007, no horário das 22 horas, tinha mais de 4.480 internautas brasileiros online. Pinheiro (2002) cita na sua matéria os números desse site, em ordem decrescente. Quanto ao perfil profissional dos homens, 50,5\% deles eram da internet, do comércio, da administração de empresas e da saúde. Em relação às mulheres, 49,5\% delas atuavam profissionalmente nas áreas da educação, do comércio, 
da administração de empresas e da saúde. Eles procuram uma mulher bonita, independente, segura, companheira, inteligente, bem-humorada, honesta. Elas procuram um homem que seja companheiro, bem-humorado, sincero, honesto, carinhoso, disposto a um relacionamento sólido. Em relação à faixa etária dos usuários, 30\% tinha entre 19 a 24 anos, 29\% entre 25 a 34 anos, $21 \%$ até 18 anos, e $20 \%$ acima dos 35 anos.

A maioria dos sites de namoro diz que perfis com fotos são dez vezes mais acessados, tem maior aceitação e recebem mais chamados para "papo direto" para o chat do próprio site, do que aqueles que não têm foto. Muitas pessoas não desejam a exposição visual, e terão como única arma de sedução inicial um perfil bem elaborado, contudo todos podem "buscar perfis" de parceiro(a)s o que fica registrado "em quem viu meu perfil" nas últimas 24 horas, nos últimos 7 dias, etc. Essa é uma segunda maneira de ser "notado" na rede, e que é mais importante para pessoas sem identidade visual. Esse tipo de site não aconselha o uso de fotos antigas nos perfis de seus membros.

Sites como o flogão, põem em destaque o flog "mais visitado", elegem o "flog mais interessante ", o "gato da semana" e "gata da semana" o que ajuda algumas pessoas a se tornarem cibercelebridades e serem vistas por um número maior de possíveis pretendentes.

O corpo humano e especialmente o feminino é exposto na rede em todos os formatos e é envolvido em todos os tipos de vestuário, do clássico "terno e gravata" cuja versão feminina é o "terninho profissional”, aos trajes de banho, uma vez que muitos sites de relacionamento não permitem o nu total, de nenhum sexo. Há internautas que desejam ser seduzidos apenas para o sexo, virtual ou não, desejo este que pode ser facilmente satisfeito.

Quais os caminhos do processo de escolha de parceiros que inicia na internet?

Para o grupo de pessoas que escolheu exibir fotos e vídeos, embora ela não permita, no primeiro contato com desconhecidos, o uso de toda a imensa linguagem corporal, ela é usada numa escala menor, pois a postura visual das pessoas seduz os(as) internautas, num grau maior ou menor, além do próprio corpo poder ser afrodisíaco. Ver e ser visto, nesse grupo, é muito similar à estratégia ancestral inicialmente descrita por etólogos, zoólogos e antropólogos. No segundo passo do flerte é necessário, na maioria dos casos, a conversa via e-mail ou on-line, em chats como o MSN ou sites de namoro.

Para um outro grupo de pessoas, mais discreto, que prefere um perfil sem imagem visual, esta é a primeira etapa e tem um grau de importância maior, 
uma vez que a linguagem verbal é $100 \%$ do que se tem para conquistar o outro, e esta pode ser transferida, numa segunda etapa, para um chat tipo MSN no qual é possível, então, para os escolhidos pretendentes, se deixar ver através de fotos.

Para os dois diferentes grupos acima citados, se a intenção é continuar usando o recurso apenas virtual, o casal pode passar para o contato quase "olhono-olho" com o auxílio de webcam que além disso permite ouvir a voz, ou ainda somente o contato viva-voz, disponíveis no MSN, no Skype, ect. Nessa situação a "idéia" que se tem da pessoa é mais próxima do que possa existir fora do mundo virtual, contudo muitos não possuem esses equipamentos e continuam o processo de conhecer o outro, pelo conteúdo do que é dito nos chats e e-mails.

O último passo é o encontro com o parceiro a ser conquistado fora da rede e isso pode acontecer de modo mais lento ou mais rápido, dependendo do momento individual dos dois. Se a flecha do desejo que foi lançada encontrou receptividade forte, pelo contato visual através das fotos de vídeos da rede e uma vez feita a confirmação através de conversas on-line interessantes, na maioria das vezes, o homem ainda é quem fará um convite para primeiro encontro não virtual, o que não raramente será rápido. Isso é a exceção à regra, uma vez que no mundo virtual paciência e tempo disponível para "garimpar" e conquistar um(a) provável pretendente compatível são essenciais.

A paquera na internet é um recurso interessante nas situações de: 1 - Ser uma pessoa tímida ou com pouca desenvoltura em ambientes públicos; $2-\mathrm{Ser}$ um(a) recém separado(a) de um relacionamento de longa duração que ainda não possui um novo grupo de amigos para sair, situação comum, na idade acima dos 40 anos; 3 - Mães com a guarda de filho(s) pequeno podem paquerar sem ter que pedir para alguém cuidá-lo(s) ou pagar uma babá; 4 - Ser mulher e tomar a iniciativa de aproximação, sem assustar os homens, que consideram isso provável, no ciberespaço; 5 - Poder ser visto(a), quando há fotos ou vídeos na rede, e despertar a atração sexual de pretendentes enquanto está realizando outras atividades da vida; 6 - Poder iniciar uma conversa com um(a) pretendente, sem precisar sair de casa para isso, o que significa economia de tempo e de dinheiro; 7 - Ter certeza, para você que pretende namorar, que ele/ela terão que conversar o mínimo com você, diferente do que acontece no clima da noite em bares e boates, no qual o barulho e o som alto são impeditivos para uma boa conversa; 8 - Usuários de computador durante muitas horas por dia, com freqüência, por motivos profissionais ou de estudo; 9 - Estar vivendo em uma nova cidade, longe 
do seu círculo de amigos; 10 - Poder selecionar perfis mais compatíveis com você e descartar os mais incompatíveis. Muitas dessas situações podem ser aplicadas às pessoas que são socialmente mais desejáveis como as bonitas, as instruídas, as confiáveis, e as em boa situação profissional, oposto do que se pensava inicialmente sobre as pessoas que usavam o recurso da paquera via internet.

No Second Life, criado em 2003, que projeta o mundo em 3D, é possível criar uma vida paralela, na qual se pode fazer de tudo, passear, namorar, ter uma família. Dia 26/8/2007 havia 9.110.340 residentes nesse mundo virtual. Sabemos que um dos aspectos que tornou o Second Life popular entre os adeptos é o sexo entre os avatares (personagens criadas), contudo ele pode ser utilizado para o treino da sedução, da aproximação afetiva e/ou sexual num primeiro momento, se a pessoa é tímida, insegura, ou tem uma sociabilidade menos desenvolvida, para num segundo momento usar o que aprendeu na sua vida principal. Saliento que pessoas com as características acima mencionadas poderiam ser beneficiadas por psicoterapia.

Rocha (2006) relata o resultado da pesquisa respondida por 2.723 pessoas, realizada no site do clicrbs.com.br, "Como você conheceu o seu par, o seu namorado(a)?” $12,12 \%$ havia começado a paquera na internet, o que demonstra uma tendência atual de um país no qual o uso da internet avança a passos galopantes.

O IBGE, em dados divulgados em dezembro de 2006, estima que em 2020 será $11,4 \%$ a proporção de pessoas com 65 anos ou mais, em relação ao total da população no Brasil. Podemos nos perguntar como será o processo de sedução na terceira-idade, com o auxílio online. Em 2020 a internet terá 25 anos no Brasil e essa será o primeiro grupo de pessoas da terceira-idade mais acostumada ao seu uso, uma vez que hoje elas têm no mínimo 42 anos, ou seja, desde os 30 anos é possível que convivam com ciberespaço por incentivo de irmãos, filhos e amigos.

O uso moderado da internet pode abrir um leque de possibilidades no universo da aproximação afetivo-sexual, contudo Brendler (2007) ressalta que temos que nos questionar se: 1 - estar ligado na internet pode nos desligar do casal, da família, dos amigos? 2 - Estar sempre conectado ao mundo através de e-mails, (e do celular, outra tecnologia da Era Fast) pode nos afastar de nós mesmos? Qual o tempo livre para cuidarmos de nós mesmos? 3 - A inexistência de empecilhos geográficos, através da internet, pode nos iludir sobre um possível aumento do número de parceiros afetivos e sexuais? $4-\mathrm{Na}$ 
internet a visão de ser "fácil e rápido" entrar num relacionamento pode nos fazer pensar que também é "fácil e rápido" sair?

O uso excessivo das tecnologias da Era Fast, como a internet, se a conexão com os outros for permanente, provoca efeito contrário a uma das suas intenções iniciais pessoais que era facilitar e melhorar a vida dos seus usuários, encurtando caminhos, para as pessoas usufruírem mais tempo livre para o lazer e o prazer. Nessa situação, de conexão constante, ela nos afasta de nós mesmos, dos vínculos afetivos e/ ou sexuais anteriormente estabelecidos.

\section{Homem ou mulher? quem é o sedutor - quem é o seduzido?}

A história nos dá vários indícios do poder da mulher em relação ao desejo sexual, um deles são as Estátuas de Vênus, que são representações da mulher como fêmea e parceira sexual, feitas há mais de 20 mil anos. Um relato da mulher como desencadeadora de paixão sexual é o "Cântico dos Cânticos", escrito pelo Rei Salomão, que reinou de 955 a 935 antes cristo e que teve 700 esposas e 300 concubinas, publicado no antigo testamento e que é uma poesia sobre a iniciação sexual de uma de suas esposas.

São Paulo diz que foi Eva que induziu Adão à transgressão. Para Santo Agostinho, o pecado cometido por Adão e Eva foi a descoberta de prazer no sexo, pois antes disso, o sexo era frio e para a procriação, e isso os levou à perda do paraíso, à perda da imortalidade. Somente no Século XII, a imagem da mulher muda no ocidente, quando surge o "amor cortês ou palaciano", a mulher é transformada na "dama pura" exaltada em poemas, canções e na literatura. Movimento que iniciou entre os poetas do sul da França sob influência do "Amor Puro" dos árabes (que cantavam e escreviam sobre mulheres que usavam véus e apenas através dos irmãos sabiam das qualidades da admirada, pois elas eram inatingíveis) e da importação de Bizâncio do culto à Virgem Maria. O amor puro era incompatível com as tentações da carne e a imagem de mulher, no ocidente, deixou de ser Eva para ser a Virgem Maria.

No Século XV surgem os cintos de Castidade, na Itália, criados com a intenção de impedir o estupro, comum nos tempos medievais, não deixavam de reforçar a crença de que as mulheres eram libertinas por natureza.

Segundo a antropóloga Fischer (1995), o forte impulso sexual da mulher encontra contrapartida no comportamento do mundo animal. Todas as fêmeas dos mamíferos ficam "excitadas" e conforme vão entrando no cio 
solicitam ativamente os machos. Esta persistência sexual feminina tem um motivo biológico. Como observou Darwin, só sobrevivem as espécies que procriam. Por isso, procurar o sexo é uma característica genética das fêmeas.

Peper (1985) diz que nos EUA as mulheres iniciam dois terços de todos os namoros que testemunhou e as entrevistadas por ele estavam bastante conscientes de haver estimulado o potencial pretendente. Já o estudo de Whyte (1978), realizado com homens e mulheres de 93 sociedades, em 72 delas os pesquisados declaravam que ambos os sexos tinham o mesmo nível de iniciativa em relação aos avanços sexuais. Peper (1985) que estudou pessoas em bar de solteiros americanos, diz que, em geral, depois da saída do bar, é que há a "transferência da iniciativa" na qual os homens começam os seus movimentos como colocar o braço em volta da mulher, beijá-la e tentar seduzi-la a aceitar a transa.

Fischer (1995) ainda cita duas características não menos sutis da sedução: 1 - a música, que é convidada a ser ouvida, que é tocada ou cantada por um do par; 2 - o convite para jantar e diz que esse é o ritual isolado mais comum entre os homens ocidentais que estão fazendo a corte.

Ao falar de atração sexual é necessário lembrar os Mapas de Amor, de Money (1986), que são um "repertório mental de cada fantasia sexoerótica individual e prática erótica”, ou seja, são os mecanismos pelos quais uma pessoa se atrai por alguém em particular. Ele afirma que esses mapas são desenvolvidos nas crianças, entre 5 e 8 anos ou até mais cedo, e são determinados pelos relacionamentos com a família, amigos como também pelas próprias experiências, que ficam registradas num padrão mental do que agrada e do que não agrada. Então, pensando nesses mapas de amor, mesmo que a mulher capriche no ritual da paquera, talvez ela não seja bem sucedida com o homem desejado, pois como Fischer (1995) também coloca, é um estimulante do desejo sexual o parceiro ser congruente com as fantasias sexuais do outro, $\mathrm{o}$ que vale para os dois sexos. Em exceção, opondo-se a essas regras, a pessoa paquerada pode aceitar o processo de aproximação não desejado, por motivos não saudáveis como, nas situaçōes em que ela está: 1 - com baixa autoestima; 2 - querendo sair da casa dos pais, a qualquer preço; 3 - vivendo uma sexualidade disfuncional e aceita o que eu chamo de "parceiro(a) secundário(a)" ou "escolha secundária”, pois esse, que não é o(a) "parceiro(a) pretendido(a)", talvez tenha mais paciência com a sua sexualidade insatisfatória; 4 - querendo usar o(a) pretendente como uma bengala, como um apoio, para uma fase difícil da vida. $\mathrm{O}$ ideal é que, nas quatro situações acima apontadas, a pessoa primeiro procurasse ajuda psicoterápica, para depois, num segundo momento, realizar uma escolha mais adequada de parceiro(a). 
Fischer (1995) ainda diz ser curioso que os ocidentais insistam no conceito de que os homens são os sedutores e as mulheres são tímidas e submissas receptoras do assédio masculino. Esta noção falsa é sem dúvida um resquício de nosso longo passado agrícola, em que as mulheres eram títeres em complicados contratos matrimoniais, envolvendo propriedades, e seu valor dependia de sua "pureza". Por isso, as moças eram devidamente vigiadas e seus impulsos sexuais desconsiderados. Mas, hoje, as mulheres ocidentais conquistaram sua liberdade sexual. Liberadas do mundo dos casamentos arranjados e da subserviência sexual, elas com freqüência tomam a iniciativa por mais sutil que seja.

O corpo feminino progrediu mais anatomicamente que o masculino, segundo os estudos de Morris (2005), visando ser mais atraente ao sexo oposto. Ele ainda ressalta que, além do poder de sedução, as características sexuais e reprodutivas do corpo da mulher o tornaram altamente evoluído e refinado (MORRIS, 2005, p. 14).

Colombino (2005) diz que sedução implica em conquista com arte e manha, o sedutor finge qualidades e exagera capacidades, persuadindo com elogios e prováveis enganos para obter favores sexuais da mulher. Classicamente todo sedutor é um "amoral', contudo há mudanças e hoje ser uma pessoa de caráter sedutor é uma lisonja. Atualmente, a sedução é mais aplicada à mulher, como sinônimo feminino do galanteio masculino.

Os homens em muitos países ocidentais são impulsionados a demonstrar mais explicitamente o seu interesse sexual, o que os faz terem um papel mais ativo, mais visível nas conquistas. Já as mulheres são educadas para disfarçar a sua atração sexual, mas ao mesmo tempo são estimuladas a valorizar a beleza física, a usar gloss, batom, salto alto, a ter um andar cambaleante, a vestir roupa justa que salienta suas curvas, ou seja, a se comportar de um jeito feminino, o que é atraente aos homens, que são mais visuais em relação ao corpo que elas, e ao mesmo tempo lhes dar a ilusão de que são eles que desencadearam o processo da aproximação afetiva e/ou sexual.

Independe se o primeiro contato foi pessoalmente ou via internet e de qual sexo lançou inicialmente a flecha mais explícita de interesse, uma vez que são inúmeras as mensagens enviadas e diferentes são as leituras que podem ser feitas pelo receptor. Em relação a manutenção do desejo sexual é importante salientar que os dois sexos têm papéis fundamentais e interligados que se retroalimentam. 


\section{A mulher e o desejo sexual}

\section{Em um contexto de sexualidade saudável}

[...] Pois quando eu te vejo

eu desejo o teu desejo[...]

(Caetano Veloso. Menino do Rio. Polygram, 1979)

O ser humano deseja sentir desejo e ser desejado, como diz o Caetano Veloso. Assim, mulheres saudáveis se permitem ter desejo sexual, uma vez que a visão do mesmo é maravilhosa. Na resposta sexual, se o desejo sexual está presente há facilitação da fase da excitação e do orgasmo.

Essas mulheres são mais livres para usar o padrão feminino do flerte de Eibl-Eibesfeldt, (1989), ou iniciar o processo de escolha e prosseguir com sucesso nos seus cinco estágios como relatado por Givens (1983) e Perper (1985): 1 - Chamar a atenção; 2 - Reconhecimento (olhares se cruzam); 3 - A conversa; 4 - O contato físico; 5 - A sincronia corporal.

Quando expostas a um ou mais dos estimulantes sexuais descritos acima por Kaplan (1995) e/ou Levine (2003) anteriormente citados, elas têm o seu apetite sexual desencadeado, uma vez que percebem o (s) estímulo(s) como afrodisíaco.

Não podemos deixar de lembrar que a mulher conta com o processo evolucionário anatômico do seu corpo a seu favor, no processo da atração sexual (MORRIS, 2005). Sabedora disso, a mulher que tem boa auto-estima vai cuidar do seu primeiro patrimônio, o seu corpo, seja investindo na sua saúde, seja valorizando os seus mais belos atributos, através das roupas, dos acessórios e dos cosméticos. A mulher ainda pode mudar o seu corpo com o objetivo de elevar a sua auto-estima e/ou torná-lo mais atraente. O Brasil foi, no ano 2000, o campeão mundial de cirurgia plástica por razões estéticas. O estímulo cultural que há em nosso país ao culto da beleza, da juventude e da sensualidade deve estar contribuindo para esse fenômeno. Sabemos que em todas as pessoas saudáveis é possível acionar o desejo sexual, independente do seu tipo físico.

A mulher ainda pode permitir-se experimentar o desejo sexual responsivo que acontece simultaneamente ou é posterior à excitação sexual, segundo o resumo da tradução do Modelo Circular publicada por Brendler (2005). Então, a mulher saudável pode aceitar o jogo erótico iniciado pelo parceiro, se envolver e ter o seu desejo sexual despertado. 
Pessoas maduras e diferenciadas questionam os valores antigos passados pelo pais sobre familiaridade ser sinônimo de intimidade, pois a primeira não requer investimento no relacionamento e no outro. Para que exista desejo sexual num relacionamento, deve existir no mínimo três entidades distintas, dois indivíduos diferenciados e o casal. A dinâmica do casal é outro ponto que pode fortalecer o apetite sexual, se houver uma conexão mais profunda com o todo do outro e do seu mundo, o que se retroalimenta.

Em um relacionamento, a quarta entidade é a família que de imaginária se tornará mais real, após a maternidade. Para manter ativo o desejo sexual, os indivíduos e o casal devem continuar existindo, com seu planos e sonhos, além dos existentes para a família. Mulher saudável e com boa auto-estima consegue estimular o homem a assumir a divisão das tarefas familiares e o cuidado com o (s) filho(s). O que lhe permitirá mais tempo e energia para cuidar de si, para investir na sua profissão e para pensar em novos encontros eróticos.

Como hoje a mulher exerce múltiplos papéis, como o de filha, de mãe, de profissional, de dona-de-casa e o papel de mulher sexuada, este último precisa ser equilibrado com os demais papéis, para que haja desejo sexual em relaçōes duradouras. Brendler (2007) cita que o ócio é mais amigo da sexualidade do que a aceleração. Pessoas saudáveis sexualmente, quando há tempo disponível, se permitem pensar em coisas e/ou atividades positivas e prazerosas, entre as quais estão o romance e a sexualidade, o que pode engatilhar o desejo sexual. Sugere ainda a criação de várias pequenas "ilhas de ócio" semanais dentro da agenda do casal, distante de tudo e de todos, para manter o namoro vivo na relação.

\section{Em um contexto de sexualidade disfuncional}

A definição da Desordem do Desejo Sexual Hipoativo (HSDD) feminino atualmente aceito é "[...] a persistente ou recorrente deficiência (ou ausência) de fantasias sexuais, pensamentos, desejo para atividade sexual (sozinho ou com o parceiro) e inabilidade para responder aos sinais sexuais que poderiam ser esperados desencadear o responsivo desejo sexual. Esses sintomas necessitam ser causa de angústia pessoal" (BASSON, 2000, p.55). Esse seria o HSDD generalizado, tipo I, mas há três subtipos de HSDD. No tipo II: há pensamentos e fantasias sexuais, há responsivo desejo sexual (aos sinais sexuais verbais, aos visuais ou aos escritos), mas a motivação para ser sexualmente ativa está ausente (exemplo: há insuficiente intimidade emocional, histórico de experiência sexual negativa, insuficiente situação de segurança, 
associação com disfunção da excitação sexual, parceiro com disfunção sexual). No tipo III, há um mínimo de pensamentos e de fantasias sexuais, há responsivo desejo sexual aos sinais sexuais visuais, aos verbais ou aos escritos, mas a motivação para ser sexualmente ativa está ausente. No tipo IV, há pensamentos e fantasias sexuais, mas há inabilidade para responder a qualquer sinal sexual (do parceiro ou de qualquer lugar) e não há motivação para ser sexualmente ativa (BASSON, 2001).

Na minha clínica sexológica o HSDD é o mais freqüente motivo de tratamento, em mulheres. No Brasil, numa pesquisa com 1.219 mulheres, a falta de desejo sexual foi relatada por 26.7\% delas (ABDO, 2004).

A mulher que sofre de Desordem do Desejo Sexual Hipoativo (HSDD) pode desenvolvê-lo por inúmeros motivos que excluem o seu par e o seu relacionamento conjugal, podendo ser secundária a outra disfunção sexual primária ou, segundo Brendler (2002), pela ausência da identificação primária dela com o papel da mulher sexuada Nessas situações é possível trabalhar somente com a mulher em terapia sexual da linha Cognitiva Comportamental. O terapeuta sexual, se perceber que o parceiro está com a sua auto-estima abalada, pelos inúmeros "não" que obteve nas suas iniciativas sexuais, pode recomendar o tratamento do casal.

Se o HSDD da mulher for secundário a uma disfunção sexual do parceiro, a conflitos conjugais ou à existência de supressores sexuais, citados por Kaplan (1995), existentes no relacionamento, é necessário que a terapia sexual seja feita pelo casal. Os supressores agem nos dois sexos, contudo pensando que, longe da paixão, alguns supressores são mais sensíveis em provocar HSDD nas mulheres, temos que citar, entre eles, a perda da atratividade pelo corpo do outro que mudou além do esperado para a idade, a ausência do namoro dentro da relação, a falta de criatividade, a excessiva familiaridade, a inexistência do ritual da sedução. A exemplo disso, podemos mencionar que talvez os dois tenham sido educados de modo tradicional, que valoriza muito o papel do homem ser um bom provedor. Este motivo associado a outras qualidades fez que ela o escolhesse, o que os levou a formar um par. Assim, se os dois estão interessados que ela reative o seu apetite sexual, além do entendimento da história de cada um e dos motivos que os levaram a se escolher, lidar com cada um dos supressores sexuais será importante.

Se após a vinda do(s) filho(s), a mulher não refletir e assumir a mulher-mãe e todos os seus encargos na família e na comunidade e ele se identificar com o filho da mãe, teremos um casamento monogâmico no qual o apetite sexual 
dele e/ou a sua sexualidade poderá será exercida fora de casa. Para essa mulher, a exaustão física e emocional, resultante do cuidar sozinha da casa e dos filhos aliado ao exercício profissional remunerado, pode ser incompatível com a presença do desejo sexual.

Se houver anulação de um dos indivíduos ou do casal em função do investimento se concentrar unicamente na família, o que é comum após a maternidade, o desejo sexual poderá diminuir (BRENDLER, 2003), para a maioria das mulheres.

Brendler (2005) salienta que na fase da integração da intimidade sexual descrita por Lobitz \& Lobitz (1986) também pode haver dificuldades sexuais, contudo elas serão mais fáceis de serem elaboradas em terapia sexual, uma vez que a intimidade está mais bem resolvida.

Brendler (2003) em uma pesquisa entre 316 pessoas consecutivas que procuraram terapia sexual, relatou que em 75 casos os dois do casal tinham disfunções sexuais, o que representou $23,73 \%$ da amostra. Noutro estudo com 32 casais disfuncionais nos quais a mulher tinha HSDD, essa autora diagnosticou em 46,87\% dos parceiros ejaculação prematura, em 40,62\% disfunção da ereção, em 9,37\% tinham HSDD e 3,12\% ejaculação retardada. A faixa etária média desses homens foi de 40 anos e 1 mês (variando de 25 a 61 anos) e dessas mulheres 38 anos e 7 meses (variando de 22 a 65anos), enquanto a média de duração do relacionamento foi 13 anos e 6 meses, variando de 7 meses a 40 anos. $51 \%$ das mulheres e $55 \%$ dos homens tinham completado o $3^{\circ}$ grau, contudo isso não os ajudou a procurar ajuda rapidamente, pois quando a terapia sexual iniciou as disfunçôes já existiam, em média, há 7 anos e 5 meses. Em 11 casais a disfunção sexual dos dois tinha como base causas prévias ao relacionamento, sendo que em 6 desses o problema surgiu desde o início da atividade sexual. Em 12 casais a disfunção sexual apareceu durante o relacionamento, sendo que em 8 desses, a disfunção surgiu, para os dois, após a metade do tempo em que conviviam. Em 4 casais a disfunção tornou-se evidente em épocas diferentes para o homem e a mulher e em 5 prontuários o tempo de início das disfunções não estava anotado.

Para a HSDD feminino é possível usar várias técnicas, no entanto, no tratamento inicial, de uma mulher com HSDD, não podemos principalmente usar o tato, o jogo sexual e o coito, pois ela poderia sentir-se pressionada a responder sexualmente ou até violentada, por isso menciono a técnica de Brendler (2005), chamada Cardápio Sexual. Essa técnica pode ser usada para qualquer tipo de HSDD, com parceiro saudável ou disfuncional e até para o tratamento da Aversão sexual, num segundo momento. 
O Cardápio Sexual é baseado no “pensar em sexualidade e sexo" através da criação de um "Repertório de cenas eróticas “que é confeccionado principalmente a partir de filmes e de livros com algum conteúdo sensual, erótico ou de romance que serão parte integrante dos "temas-de-casa” da psicoterapia da linha Cognitiva Comportamental. Filmes com duas a três cenas de sexo são o material inicial preferido pelas mulheres que utilizam o Cardápio Sexual. Ao pensar nas cenas do Cardápio Sexual, várias vezes ao dia, durante o tratamento, será criado o hábito de pensar positivamente em sexualidade, o que facilitará a receptividade ao parceiro e o retorno do desejo sexual.

Se os dois são disfuncionais e o parceiro não pode ser o desencadeador do desejo sexual, quando ele está com a sua auto-estima abalada e nas situações em que ele está com alguma disfunção sexual, mas o seu tratamento já avançou e ele já tem um resgate parcial dos problemas citados acima, podemos usar o Cardápio Sexual para acionar o desejo sexual dela e, posteriormente, através dessa "nova" mulher, despertar o apetite sexual dele. Se a técnica do "coito proibido" ainda for recomendado, o Cardápio Sexual pode ser usado também antes do encontro a dois, a fim de passar a mente dela da neutralidade sexual para um "estado erótico", o que tem respaldo na literatura, pois Kaplan (1995) já sugeria o uso da fantasia sexual para levar os pacientes a um "humor erótico" anterior à abordagem do(a) parceiro(a). Assim, o clima sensual e erótico criado pela mulher, em situação que não incluiu o coito, irá adicionar memória positiva sexual, a esse casal, o que ajudará num resgate maior da sexualidade funcional. À medida que for reativado o desejo sexual dela, com o objetivo de desencadear o apetite sexual dele, ela conseguirá ser mais sensual no seu jeito de ser, de andar, de falar e de se vestir, pelo menos na intimidade.Será mais natural para ela sugerir "novidades" dentro do jogo erótico, além de jantares românticos e pequenas viagens, dando vida ao relacionamento anteriormente desgastado pela disfunção sexual dos dois.

Na psicoterapia da linha Cognitiva Comportamental para tratar o desejo sexual hipoativo, além do Cardápio Sexual Brendler (2003) ressalta ser importante o terapeuta sexual trabalhar com o casal ou a pessoa os itens: 1 - $\mathrm{O}$ investimento em si mesmo: $1 \mathrm{~A}$ - estar em constante estado de crescimento, ser admirável; 1B - Não descuidar da aparência física. 2 - Investir no relacionamento: $2 \mathrm{~A}$ - Tentar ouvir o outro como também iniciar e manter o diálogo; $2 \mathrm{~B}$ - Criar tempo disponível para o relacionamento; $2 \mathrm{C}$-Mudar o lugar do encontro erótico; 2D-Delimitar a privacidade do casal; 3 . Investir no outro: $3 \mathrm{~A}$ - Estar atento para as necessidades, os desejos e os interesses do outro; $3 \mathrm{~B}$ - Estimular e validar o comportamento do outro. Aponto ainda um outro item, o $4^{\circ}$ - Investir na negociação da divisão do trabalho em casa: estimular o homem a dividir as tarefas domésticas e o cuidado com o(s) filho(s). 


\section{Referências bibliográficas}

ABDO, C.H.N; OLIVEIRA, WM; MOREIRA, ED; FITTITPALDI, JAS. Prevalence of sexual dysfunction and correlated conditions in a sample of Brazilian women - results of Brazilian Study on Sexual Behavior (BSSB). International Journal of Impotence Research, v.16 (2) p. 160-166, 2004. USA: Nature Publishing Group, 2004.

BASSON, R. Are the complexities of Women's sexual function reflected in the new consensus definitions of dysfunction? Journal of Sex \& Marital Therapy, v. 27 (2) : 105-112, 2001. Philadelphia, PA:Taylor \& Francis, 2001.

. The female sexual response: a different model. Journal of Sex \& Marital Therapy, 26: p.51-65, 2000. Philadelphia, PA: Taylor \& Francis, 2000.

BRENDLER, J. A ausência de identificação feminina com a 'mulher sexuada' aparece em relacionamentos de longa duração. Revista Brasileira de Sexualidade Humana, v.13, n.1 p.15 - 19, 2002. SBRASH. São Paulo: Iglu, 2002.

. Incidence and profile of couples in which both partners have a sexual dysfunction. In: World Congress of Sexology, $16^{\text {th }}$. Havana, 2003. Abstract Book. Havana, World Association for Sexology, 2003 p. 81.

Women with hypoactive sexual desire (HSDD) and their male dysfunctional partners. In: World Congress of Sexology, $16^{\text {th }}$. Havana, 2003. Abstract Book. Havana, World Association for Sexology, 2003 p. 81.

- A maternidade, o significado de ser mulher e o desejo sexual Hipoativo. In: 6a Jornada Gaúcha de sexualidade Humana - "Os Sentimentos”. Porto Alegre: 2003. Anais. Porto Alegre: Sociedade Brasileira de Estudos em Sexualidade Humana, 2003, p.11.

. A nova resposta sexual feminina baseada no "modelo circular" e a clínica sexológica". In: Congresso Brasileiro de Sexualidade Humana, 10. Porto Alegre, 2005. Anais. Porto Alegre: Sociedade Brasileira de Estudos em Sexualidade Humana, 2005 p. 55 -56.

- O atendimento psicoterápico: o casal e a queixa sexual. In: X Congresso Brasileiro de Sexualidade Humana. Porto Alegre, 2005. Anais. Porto Alegre, Sociedade Brasileira de Estudos em Sexualidade Humana, 2005 p. 46.

. Cardápio Sexual: um novo tratamento baseado no "pensar em sexo" para mulheres com desejo sexual hipoativo (HSDD). Revista 
Brasileira de Sexualidade Humana v. 16 n.1 p. 89-104, 2005. SBRASH. São Paulo: Iglu, 2005.

.The Fast Era, love relationships, and sexuality. In: $1^{\text {ST }}$ World Congress for Sexual Health and $18^{\text {th }}$ Congress of World Association for Sexual Health. Sydney, 2007. Abstract Book. Sydney: World Association for Sexual Health, 2007, p.181.

COLOMBINO, A.F. La Danza del cortejo e sus mutiples variables. Revista Brasileira de Sexualidade Humana, v. 16, n.2, p.183-93, 2005. SBRASH. São Paulo: Iglu, 2005.

EIBL-EIBESFELDT, I.. Human Ethology. New York: Aldine Gruyter, 1989.

FISHER, H. Anatomia do Amor. A história natural da monogamia, do adultério e do divórcio. São Paulo: Editora Eureka, 1995.

GIVENS, D. B. Love signals: How to attract a mate. New York: crown, 1983.

KAPLAN, H.S. The Sexual Desire Disorders. Disfunctional Regulation of Sexual Motivation. New York: Brunner/Mazel, Publishers, 1995.

LEVINE, S.B. The Nature of sexual desire: A clinician's perspective. Archives of Sexual Behavior, v. 32, n .3, p.279-285, 2003. Kluwer Academicl Plenum Publishers, Dordrecht, The Netherlands, 2003.

LOBITZ, C.W, LOBITZ, K.G. Resolving the sexual intimacy paradox: a developmental model for the treatment of sexual desire disorders. Journal of Sex \& Marital Therapy, v.22 n.2, p.71-84. Brunner/Mazel Publishers, New York, 1996.

MONEY, J. Lovemaps: Clinical concepts of sexual / erotic health and pathology. Paraphilia and gender transposition in childhood, adolescence and maturity. New York: Irvington Publishers, 1986.

MORRIS, D. Comportamento íntimo. Rio de Janeiro: José Olímpio, 1983. .A mulher nua. Estudo do Corpo feminino. São Paulo: Editora Globo, 2005.

PEASE, A.; PEASE, B. Por que os homens fazem sexo e as mulheres fazem amor? Uma visão científica (e bem-humorada) de nossas diferenças. Rio de Janeiro: sextante, 2000.

PERPER, T. Sex signals: the biology of love. Philadel phia: ISI Press, 1985.

PINHEIRO, D. Tecla comigo, vai... Revista Veja. São Paulo, 20 de nov. 2002. p. 83.

ROCHA, P. As promessas da noite. Zero Hora. Porto Alegre, dia 5 nov. 2006. Caderno Donna, p.6.

ROSEN, R.C.; RILEY, A.; WAGNER, G.; OSTERLOH, I.H.; KIRKPATRICK, J.; MISHRA, A. The International Index of Erectile 
Dysfunction (IIEF): A multidimensional scale for assessment of erectile dysfunction. Urology, 49, p.822-830, 1997. Sociéte Internationale d' Urologie. USA: Elsevier, 1997.

WHYTE, M.K. The Status of Women in Preindustrial Societies. USA: Princeton Univ. Press, 1978.

ZERO HORA. Brasil é líder em navegação. O País tem 17,9 milhões de internautas residências ativos". Zero Hora. Porto Alegre, 7 julho de 2007, p.17. 